\title{
37. SEISMIC STRATIGRAPHY AND GEOLOGIC DEVELOPMENT OF AN OPEN-OCEAN CARBONATE SLOPE: THE NORTHERN MARGIN OF LITTLE BAHAMA BANK ${ }^{1,2}$
}

\author{
H. Mark Van Buren, Department of Geology and Moss Landing Marine Laboratories, San Jose State University, \\ San Jose, California \\ and \\ Henry T. Mullins, Department of Geology, Heroy Geology Laboratory, Syracuse University, Syracuse, New York
}

\begin{abstract}
Carbonate slope development north of Little Bahama Bank (LBB) has been investigated via a seismic stratigraphic analysis of approximately $1350 \mathrm{~km}$ of air-gun seismic reflection profiles. Slope development is shown to be complex because of the interaction of slope accretion, sediment bypassing, and submarine erosion to produce a single open-ocean carbonate slope. The present slope north of LBB did not develop until after the complete drowning of the southern Blake Plateau near the end of the Cretaceous. Beginning in the early Tertiary and continuing through the present, this slope has accreted laterally by the accumulation of periplatform oozes along its upper slope, whereas submarine slides and sediment gravity flows have bypassed the upper slope, resulting in a lower slope apron of slide blocks, turbidites, and debris flows. Slope sedimentation north of LBB was more or less continuous, with the exception of a late Oligocene erosional event that may be correlative with the " $\mathrm{A}$ "" unconformity in the western North Atlantic.

Overall, slope accretion, sediment bypassing, and submarine erosion have acted together during plate tectonic drift to higher latitudes, numerous sea-level fluctuations, and local tectonics to produce a single, open-ocean carbonate slope. This area is well-suited for future Deep Sea Drilling Project drill sites to evaluate the demise of a shallow-water carbonate platform and subsequent carbonate slope development.
\end{abstract}

\section{INTRODUCTION}

The geologic development of carbonate slopes is one of the least-known aspects of the overall evolution of carbonate platforms. In "modern", environments, previous studies of carbonate slopes (Mullins and Neumann, 1979; Schlager and Chermak, 1979; Mullins et al., 1980a, 1980b; Crevello and Schlager, 1980) have concentrated on lateral facies relationships, and have been limited by the relative inaccessability of these deepwater environments to direct observations, as well as by relatively steep gradients that limit the resolution capabilities of conventional seismic reflection profilers.

In an attempt to conceptualize carbonate slope development, Mullins and Neumann (1979) proposed a classification of carbonate slopes that was based on: (1) whether a particular slope is presently accreting or eroding; (2) whether the accretion is lateral or extensional; (3) whether lateral growth occurs along the open ocean, and open seaway, or a closed seaway; and (4) whether the slope is adjacent to a windward or leeward-oriented shallow-bank edge (with respect to the physical energy flux at the sea surface). This latter point is of significance to the supply of coarse-grained sediment from the bank top to the adjacent slope, which Hine et al. (1981) have demonstrated to be extensive along leeward bank margins.

Schlager and Ginsburg (1981) have recently proposed a developmental scheme for carbonate slopes that utiliz-

\footnotetext{
${ }^{1}$ Sheridan, R. E., Gradstein, F. M., et al., Init. Repts. DSDP, 76: Washington (U.S. Govt, Printing Office).

2 Please direct all correspondence, including requests for reprints, to Dr. Mullins at Syracuse University.
}

es the accreting and eroding types of Mullins and Neumann (1979) as well as the bypass type of Schlager and Chermak (1979). On the basis of slope profile, Schlager and Ginsburg (1981) suggest that during the evolution of carbonate platforms, carbonate slopes evolve naturally from accretion to bypassing to erosion types. Accretion slopes have gentle profiles that suggest outbuilding by submarine slump and debris-flow processes; along bypass slopes, turbidity current processes dominate as the overall slope profile increases; and erosion slopes evolve from bypass slopes as a result of erosion by turbidity currents that outpace perennial sedimentation (Schlager and Ginsburg, 1981).

The location of our present study area is illustrated in Figure 1. Sedimentologically, this slope north of Little Bahama Bank (LBB) is an excellent example of a bypass slope (Mullins and Neumann, 1979), yet its overall slope profile is, for the most part, similar to those classified as accretion slopes by Schlager and Ginsburg (1981). Previous work on this slope by Mullins and Neumann (1979) was based on only a few reflection profiles and a handful of cores. We returned to this slope to conduct a detailed investigation in order to understand more fully the geologic development of carbonate slopes. In this chapter we concentrate on the geologic development of this slope, principally focussing on a stratigraphic analysis of our seismic reflection data. Details of our sedimentological studies have been (Mullins, Newton, et al., 1981 ) or are in the process of being presented elsewhere.

\section{METHODS}

Approximately $1350 \mathrm{~km}$ of high-resolution, single-channel, airgun, seismic reflection profiles were collected from the slope north of LBB. A grid of track lines, with an approximate spacing of $5 \mathrm{~km}$, was 


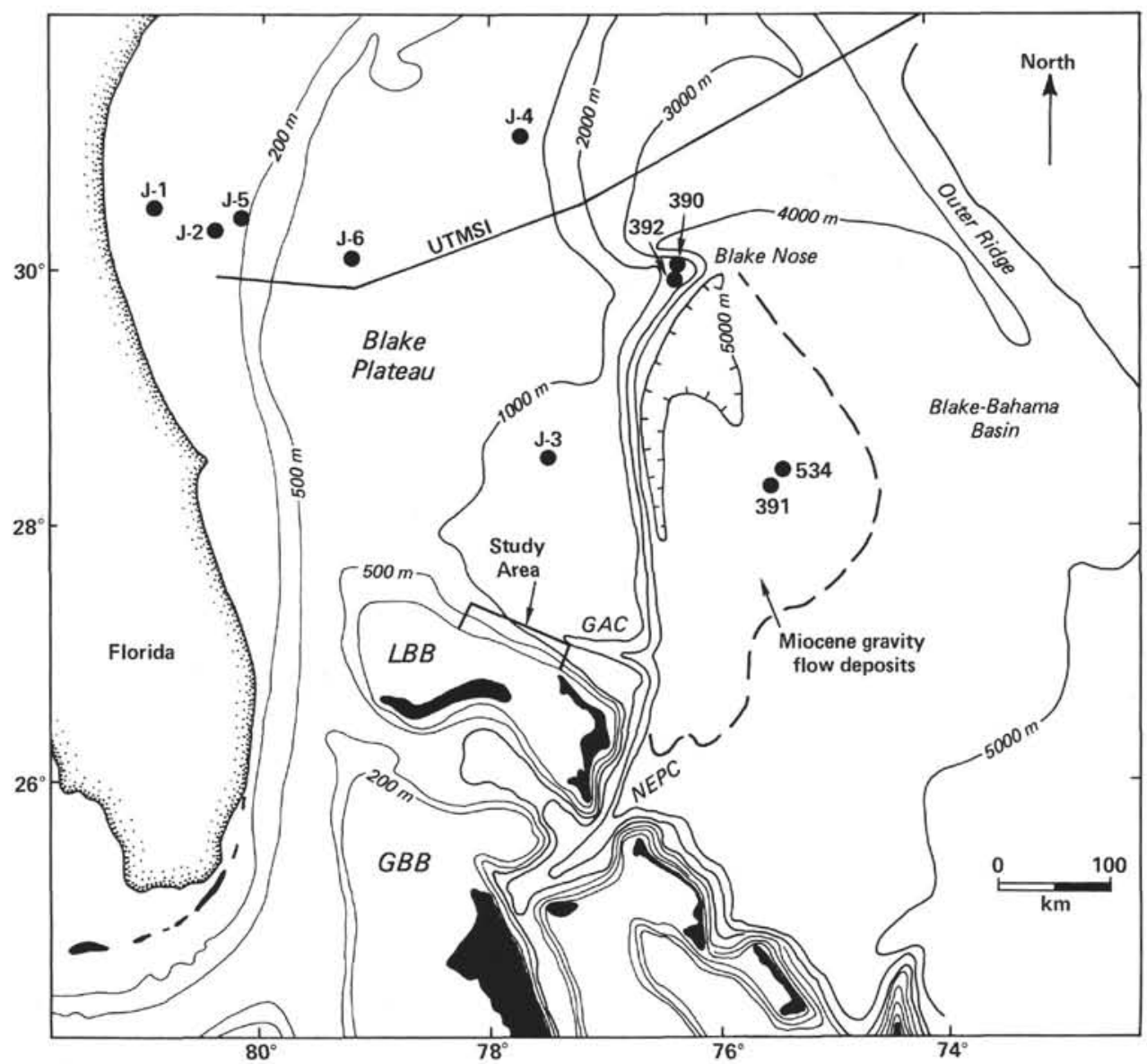

Figure 1. Index map of the Blake Plateau-northern Bahama Platform region. (Note location of study area and its relationship to the Great Abaco Canyon [GAC]. Also shown are locations of JOIDES [J-1 to J-6] and DSDP [390-392; 534] drill holes, as well as the multichannel seismic line [UTMSI] of Shipley et al. [1978]. Distribution of Miocene gravity flow deposits in the Blake-Bahama Basin [heavy dashed line] is based on Benson, Sheridan, et al. [1978]. Islands are in black. GBB = Great Bahama Bank; LBB = Little Bahama Bank; NEPC = Northeast Providence Channel. Based on King [1969].)

run both parallel and perpendicular to the northern shelf edge of LBB in order to facilitate seismic stratigraphic correlations (Fig. 2). Seismic reflection, total intensity magnetic, and $3.5-\mathrm{kHz}$ PDR (precision depth recorder) profiles were collected simultaneously along track lines. Reflection profiles were obtained aboard the Eastward in July through August 1979 by the firing of a single 5 -in. ${ }^{3}$ air gun every $3 \mathrm{~s}$. Reflections were received by a single-channel streamer equipped with a preamplifier, filtered at $63 / 205 \mathrm{~Hz}$, and graphically recorded.

Seismic stratigraphic analyses are based on criteria in Payton (1977). Depositional sequence boundaries (i.e., unconformities) are defined by reflector terminations (onlap, downlap, truncation) whenever possible (Mitchum, Vail, and Thompson, 1977) and then compared with the global sea-level curve of Vail et al. (1977) for possible correlations. Seismic facies are identified and interpreted using reflection parameters such as configuration, continuity, amplitude, frequency, and interval velocity (Mitchum, Vail, and Sangree, 1977; Sangree and Widmier, 1977; Sheridan, 1981). Interval velocities are based on comparison of our reflection profiles with available refraction data (profile 21 of Sheridan et al., 1966). Major reflectors are identified by comparison with profiles presented in Ewing et al. (1966) and then correlated with available drill hole data (JOIDES, 1965; Sheridan and Enos, 1979), as well as with preexisting seismic stratigraphic units defined for the northern Blake Plateau (Fig. 1; Shipley et al., 1978). In addition to geophysical profiles, we have also collected 73 bottom samples from this study area (Fig. 2), some of which were previously reported in Mullins and Neumann (1979).

\section{REGIONAL SETTING}

The northern margin of LBB marks the present-day topographic boundary between the relatively deep-water Blake Plateau on the north and the shallow-water Bahama Platform to the south (Fig. 1). Morphologically, this margin can be divided into a relatively steep $\left(\sim 4^{\circ}\right)$ upper slope (200-900 m), dissected by numerous slope gullies or canyons, and a more gentle $\left(\sim 1-2^{\circ}\right)$ lower slope $(900-1300+\mathrm{m})$ or basin margin rise (Fig. 3).

Northeast of LBB lies the Great Abaco Canyon, whose location and origin have been linked to the Great Abaco Fracture Zone (Sheridan and Osburn, 1975; Benson, Sheridan, et al., 1978; Mullins et al., 1982). This Canyon extends from depths of $\sim 1300 \mathrm{~m}$ north of LBB to below $4800 \mathrm{~m}$ in the adjacent Blake-Bahama Basin (Fig. 1).

The shallow-bank edge of northern LBB is basically a reef-dominated margin with numerous back-reef sand shoals and lagoons (Hine and Neumann, 1977; Locker, 1980). However, Lighty (1981) has shown that this barrier reef died approximately $3500 \mathrm{yr}$. ago due to initial 


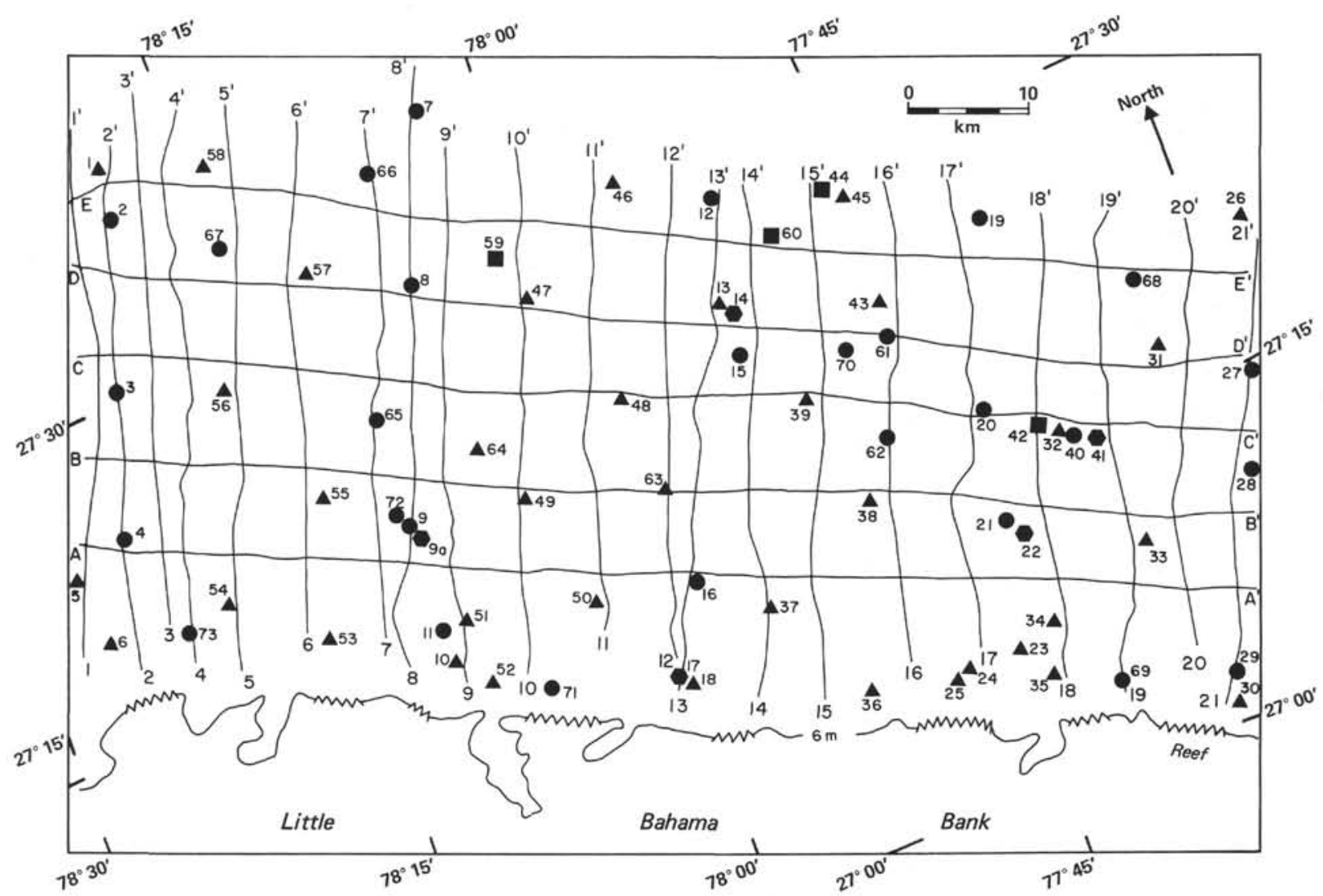

Figure 2. Location of air-gun, seismic reflection profile track lines and bottom samples collected north of Little Bahama Bank. (See Fig. 1 for location of study area. Legend: black circle = piston core; square = rock dredge; triangle $=$ Shipek grab; hexagon = bottom camera station. Numbers refer to specific samples.)

flooding of the back-reef platform. In terms of physical energy flux, this margin is windward facing, which results in a net on-bank transport of coarse-grained sediment (Hine and Neumann, 1977).

\section{SEISMIC STRATIGRAPHY}

Seismic stratigraphic analysis of our reflection profiles has resulted in the division of the slope north of LBB into four depositional sequences (NLBB series). These sequences have tentatively been correlated with sequences BP-4 to BP-1 of Shipley et al. (1978; Fig. 1). We wish to point out, however, that no drill hole data exist in our immediate study area, and that the following sequence correlations are, at present, only tentative. Deep-sea drilling data will be needed to test and refine these sequence boundaries. In the sections that follow, we define and interpret each of these four depositional sequences, beginning with the oldest.

\section{NLBB-4 (Pre-Campanian)}

The base of NLBB-4 was not recorded on any of our reflection profiles, and its top is conformable with the overlying sequence. This depositional sequence is defined not by reflector terminations, as are the other sequences, but rather by an amplitude anomaly (Figs. 4, $5)$.

In the western portion of our study area, sequence NLBB-4 is characterized by a high amplitude, even, par- allel continuous seismic facies, and by an interval velocity of $4.56 \mathrm{~km} / \mathrm{s}$, which we interpret as shallow-water, platform interior carbonates. However, in the eastern portion of our study area (east of profile 6 in Fig. 2), this sequence is characterized by a discontinuous, wavy, irregular, subparallel to chaotic seismic facies. Such facies could have resulted from either structural deformation and/or sedimentation in a variable, high-energy (sediment gravity flow) environment (Mitchum, Vail, and Sangree, 1977).

The top of NLBB-4 correlates with reflector 4 of Ewing et al. (1966), which Sheridan and Enos (1979) have proposed as the boundary between Santonian and Campanian limestones. However, Shipley et al. (1978) correlated reflector 4 with the mid-Cenomanian, and interpretation later contested by Sheridan and Enos (1979). We assume that reflector 4 of Ewing et al. (1966) is at the Santonian/Campanian boundary $(\sim 80 \mathrm{Ma})$ as proposed by Sheridan and Enos (1979). We have also tentatively correlated the top of NLBB-4 with the top of sequence BP-4 (Santonian to mid-Cenomanian) of Shipley et al. (1978; Fig. 6).

\section{NLBB-3 (Campanian-Maestrichtian)}

The base of sequence NLBB-3 is conformable with the top of the underlying sequence (NLBB-4) and is defined by the same amplitude anomaly. The top of NLBB3 , however, is defined by downlap of the overlying se- 


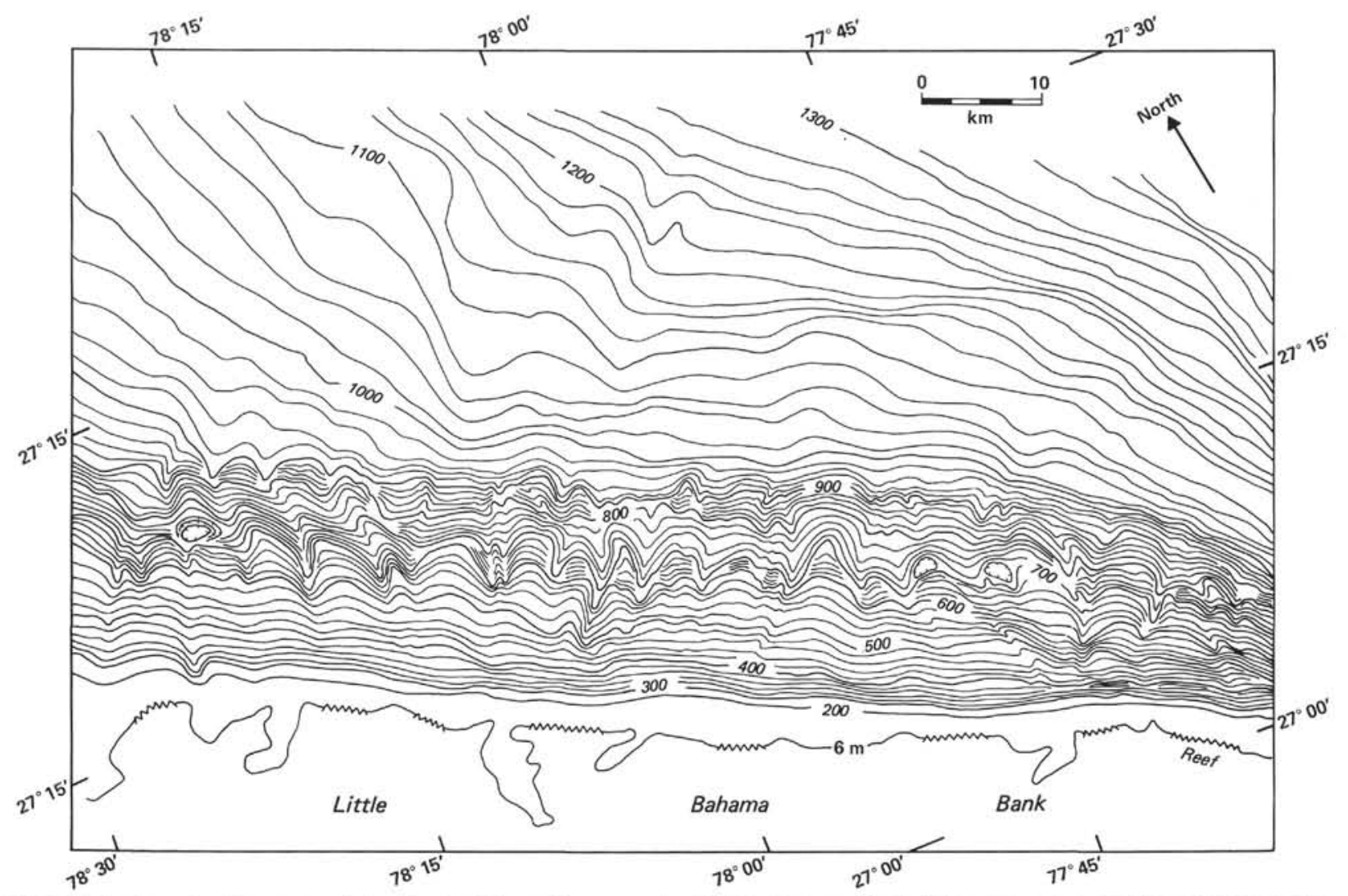

Figure 3. Bathymetry (in uncorrected meters) of the northern margin of Little Bahama Bank. (Map was constructed from 3.5-kHz PDR profiles collected along the track lines shown in Fig. 2. Note the natural division of this area into a relatively steep, dissected upper slope at depths of $200-900 \mathrm{~m}$, and a relatively smooth, gentle lower slope at depths $>900 \mathrm{~m}$. Deflection of contours to the west reflect influence of a carbonate sediment drift off the northwest corner of Little Bahama Bank [Mullins et al., 1980b]. Great Abaco Canyon is present to northeast of this area at depths $>1300 \mathrm{~m}$. Closed contours are major slide scars.)

quence (NLBB-2; Figs. 4, 5). Refraction data of Sherican et al. (1966) indicate the presence of a $3.03-\mathrm{km} / \mathrm{s}$ layer in our study area that was not found elsewhere on the Blake Plateau, which we have tentatively correlated with NLBB-3. This sequence thickens to the east from approximately 250 to $450 \mathrm{~m}$ (Fig. 5), which agrees well with refraction data in Ewing et al. (1966). The seismic facies of sequence NLBB-3 also vary laterally from west to east, in a fashion similar to that found in NLBB-4 (Figs. 4, 5).

We tentatively correlate sequence NLBB-3 with sequence BP-3 of Shipley et al. (1978), which they interpreted to be Campanian to Maestrichtian. If correct, the top of this sequence would be correlative with a drop in sea level at the end of the Cretaceous (Vail et al., 1977; Fig. 6).

\section{NLBB-2 (Paleocene-late Oligocene)}

The base of this depositional sequence is defined by downlap onto the underlying sequence and its top by erosional truncation as well as downlap of the overlying sequence (Figs. 4, 5). Refraction data of Sheridan et al. (1966) suggest an interval velocity of $2.4 \mathrm{~km} / \mathrm{s}$ and indicate that this sequence is as much as $880 \mathrm{~m}$ thick along the upper slope, but thins rapidly seaward to a thickness of only $280 \mathrm{~m}$ near the upper/lower slope boundary.

Unlike the seismic facies in sequences NLBB-4 and NLBB-3, which change laterally from west to east, the seismic facies in NLBB-2 vary seaward from south to north. Beneath the upper slope, NLBB-2 is characterized by relatively low amplitude, semicontinuous, wavy parallel reflections that we interpret as fine-grained periplatform oozes. Seaward, beneath the lower slope, this same sequence is characterized by chaotic reflections (Fig. 4) with occasional contorted, discordant reflectors (Fig. 7), which grade laterally into semicontinuous, subparallel reflections. Our interpretation of these lowerslope seismic facies is that they represent a proximal to distal transition of submarine slide and sediment gravity flow deposits.

On the basis of reflector truncation at the top of NLBB-2 (Fig. 8), we infer the presence of a submarine erosional unconformity. We tentatively correlate this unconformity with the late Oligocene drop in sea level (Fig. 6), approximately $30 \mathrm{Ma}$, which is a time of known submarine erosion in the western North Atlantic (Paull and Dillon, 1980; Tucholke, 1981). If correct, sequence NLBB-2 would be correlative with sequence BP-2 of Shipley et al. (1978), which they interpreted as Paleocene to late Oligocene.

\section{NLBB-1 (late Oligocene-Recent)}

The base of this depositional sequence is defined by distinct downlap onto the underlying sequence (Fig. 8) and its top by the present sediment/water interface (Figs. 4, 5). Refraction data suggest an interval velocity 

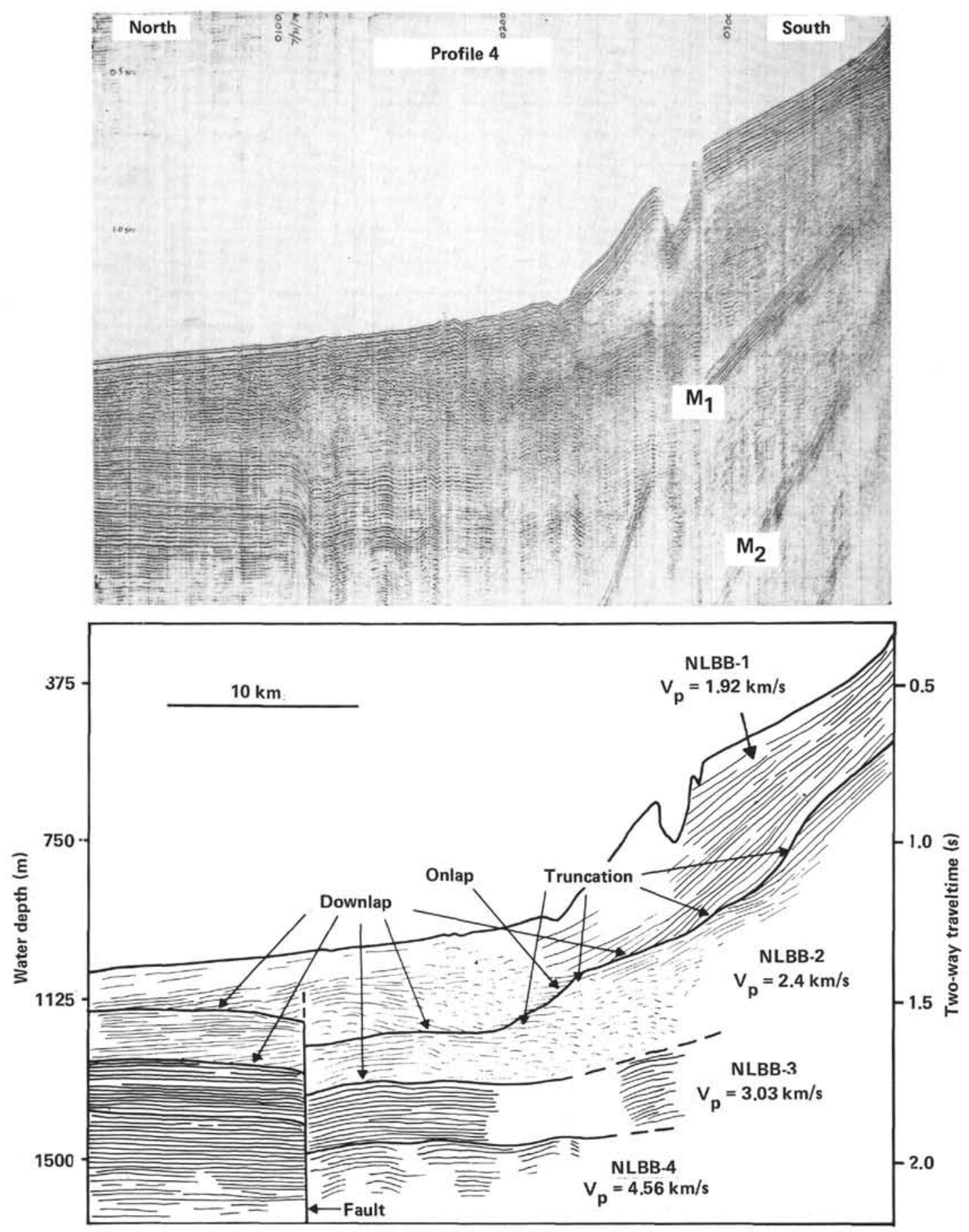

Figure 4. Photograph and line drawing interpretation of air-gun reflection profile 4. (For location of profile, see Fig. 2. $\mathrm{M}_{1}$ and $\mathrm{M}_{2}$ denote first and second water bottom multiples, respectively. Vertical exageration is approximately $22 \times \cdot \mathrm{v}_{\mathrm{p}}=$ compressional wave velocity.)

of 1.7 to $2.0 \mathrm{~km} / \mathrm{s}$, which was assumed to be $1.92 \mathrm{~km} / \mathrm{s}$ in our study area by Sheridan et al. (1966).

The seismic facies of NLBB-1 vary from south to north much as they do in NLBB-2. Along the upper slope, NLBB-1 is characterized by low-amplitude, continuous, parallel to subparallel reflections. The entire package forms a slope front fill facies (Mitchum, Vail, and Sangree, 1977) that exhibits occasional updip onlap and pronounced downdip downlap (Fig. 8). We interpret this seismic facies to consist primarily of fine-grained periplatform oozes-an interpretation supported by core samples that have recovered such sediment (Fig. 9). In contrast, the lower slope is characterized by chaotic to discontinuous reflections, which we interpret as proximal to distal sediment gravity flow deposits. Cores taken from the lower slope support this interpretation, in 


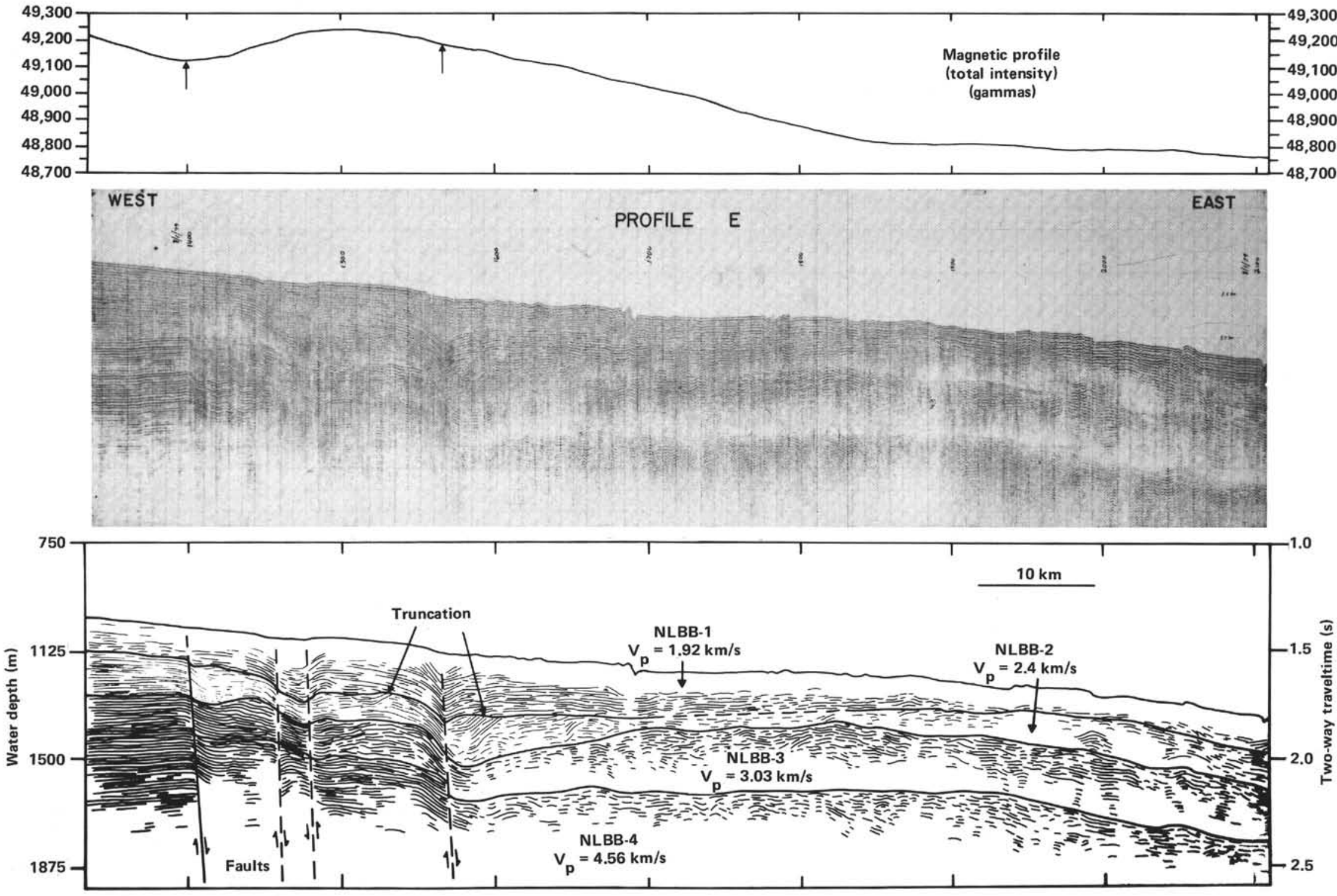

Figure 5. Total intensity magnetic, air-gun reflection profile and line drawing interpretation of profile E. (Arrows on the magnetic profile mark limits of faulting as seen on the reflection profile. For location, see Fig. 2. Vertical exaggeration is approximately $22 \times v_{p}=$ compressional wave velocity. 


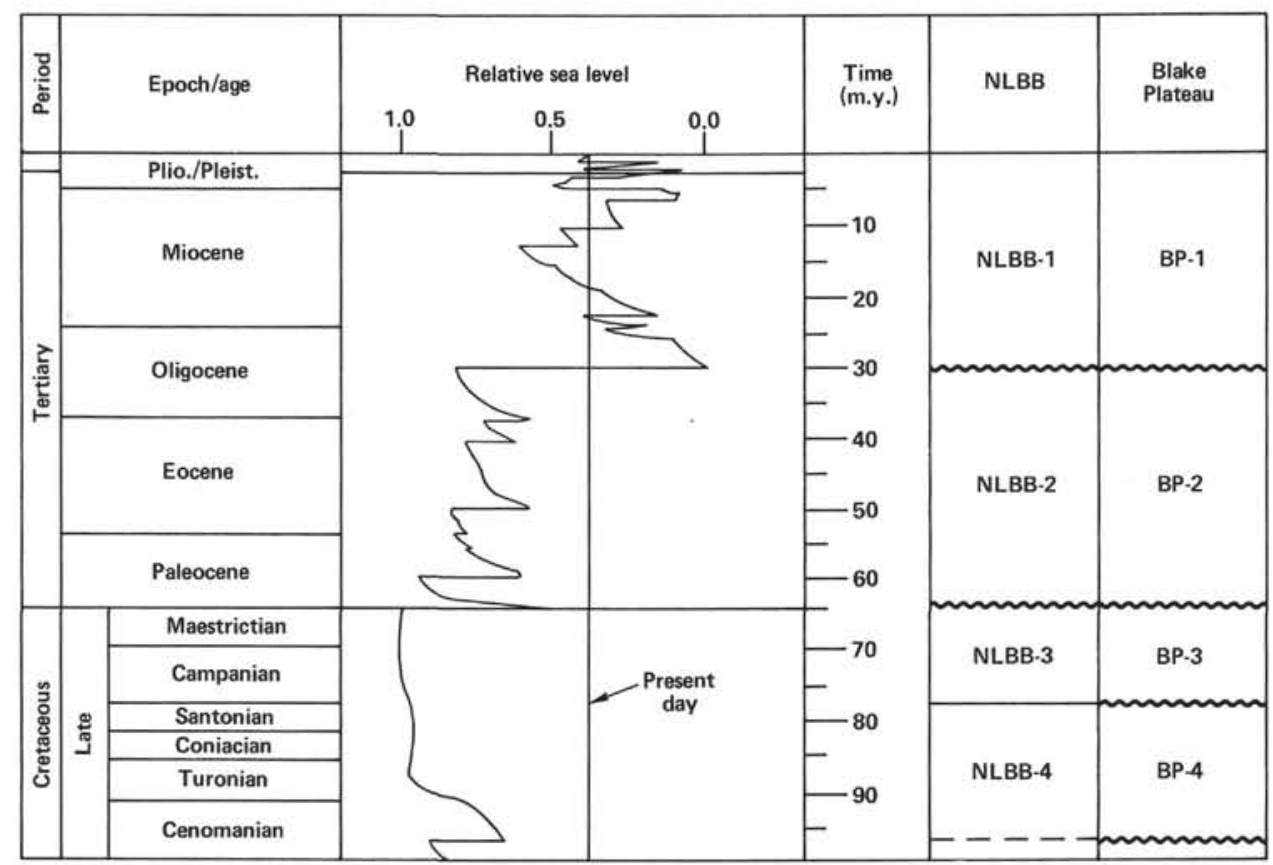

Figure 6. Schematic correlation chart showing inferred ages of NLBB depositional sequences and their possible correlation to the Vail et al. (1977) sea-level curve as well as to the depositional sequences (BP-4 to BP-1) of Shipley et al. (1978) from northern Blake Plateau. (Wavy lines represent unconformities; solid lines conformity; dashed line, uncertain boundary.)

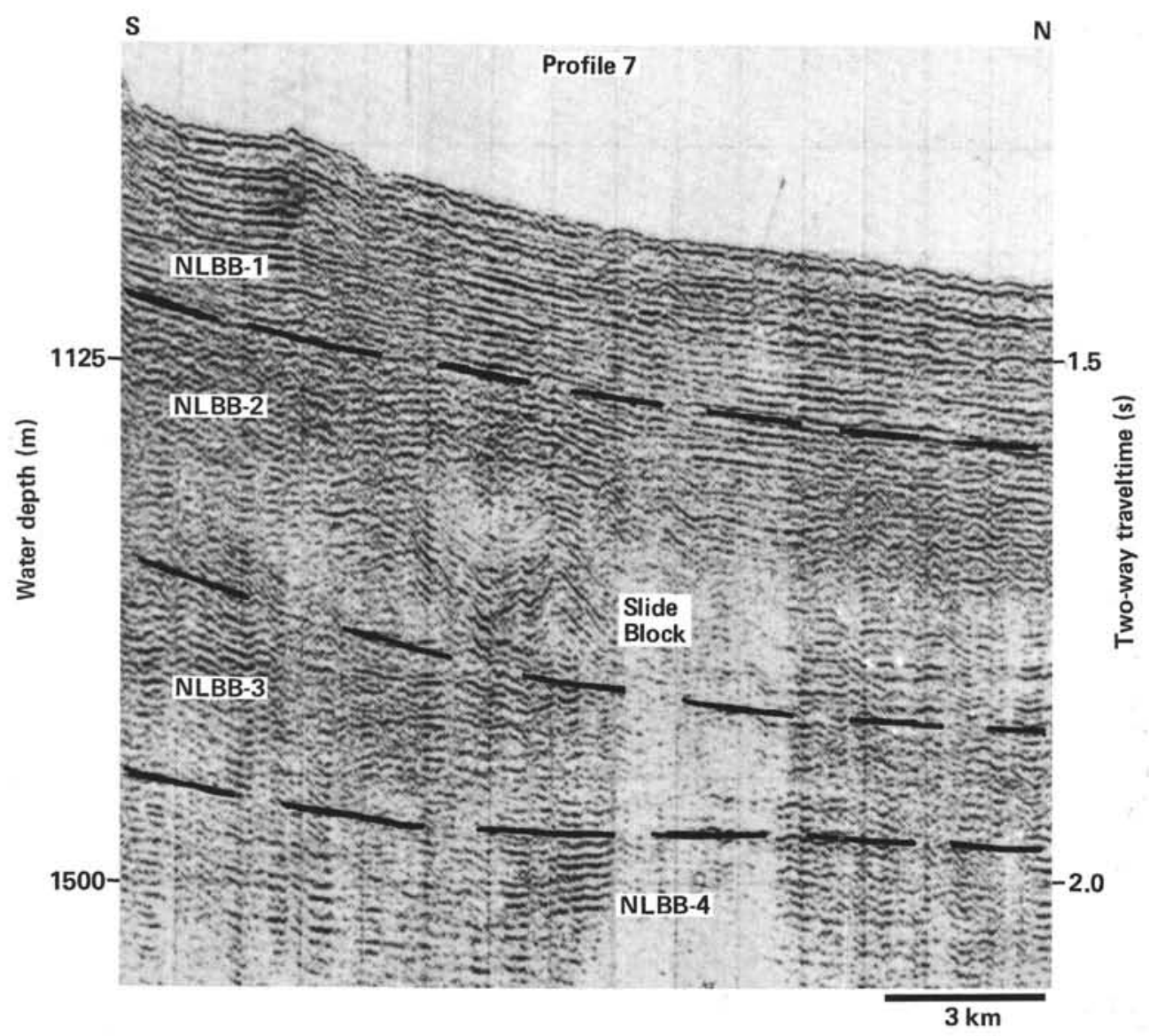

Figure 7. Photograph of lower slope portion of air-gun profile 7 with sequence boundaries highlighted. (Note contorted, discordant reflectors at the base of NLBB-2, which we interpret as a large slide block. For location of profile, see Fig. 2. Vertical exaggeration is approximately $22 \times$.) 


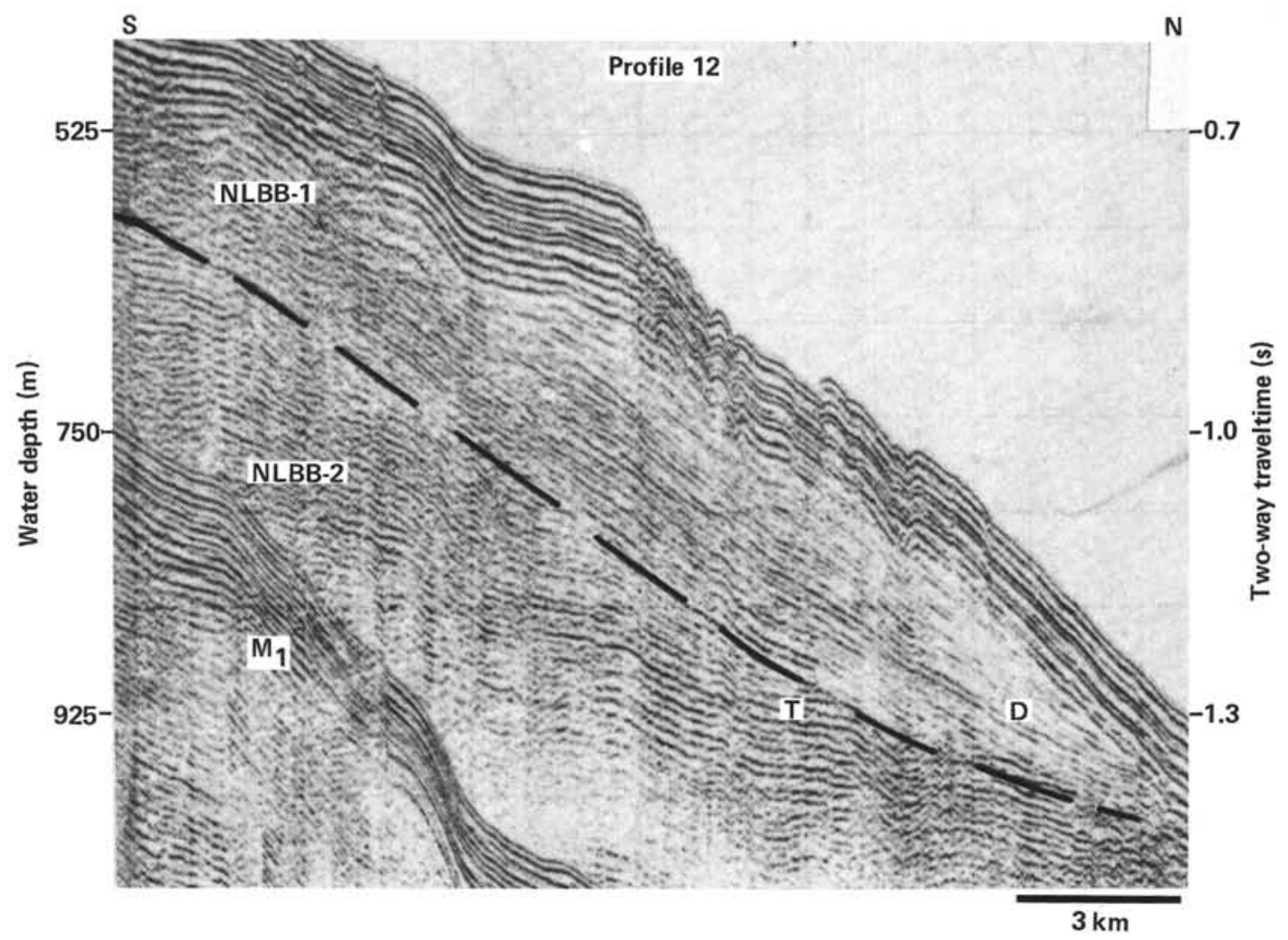

Figure 8. Photograph of upper slope portion of air-gun profile 12 with sequence boundaries highlighted. (Note downlap [D] of slope front fill facies of NLBB-1 onto sequence NLBB-2 as well as truncated reflectors [T] at the top of NLBB-2. Also present is a contemporary slide scar, indicating that submarine sliding continues to be an important process along the upper slope through the Recent. For location of profile, see Fig. 2. Vertical exaggeration is approximately $22 \times . \mathrm{M}_{1}=$ multiple reflection.)

that they have revealed the presence of very coarsegrained carbonate turbidites and debris-flow deposits (Figs. 10, 11).

\section{GEOLOGIC DEVELOPMENT}

Based on our seismic stratigraphic interpretations, it is apparent that the geologic development of the carbonate slope north of LBB has been complex (Table 1). Our data reveal abrupt seismic facies changes that occur both vertically and laterally.

Depositional sequences NLBB-4 and NLBB-3 are both similar in that they display seismic facies typical of shallow-water carbonate platform interior sediments in the western portion of the study area and seismic facies more typical of slope or basinal sedimentation to the east (Fig. 5). On this basis, we suggest that a carbonate slope existed prior to deposition of the top of NLBB-4 (Santonian) along the northeastern margin of LBB, but that similar deep-water conditions did not exist along the northwestern margin of LBB until after deposition of NLBB-3 (end of the Cretaceous).

Such a lateral change in deposition north of LBB probably reflects the presence of the Great Abaco Canyon, which is pre-Santonian (Ewing et al., 1966; Mullins et al., 1982). Structure contour maps (Figs. 12, 13) on the top of NLBB-4 (reflector 4) clearly illustrate evidence for a structural depression northeast of LBB in the present vicinity of the Great Abaco Canyon. These data, in conjunction with our reflection data, suggest that the Great Abaco Canyon area was a significant structural depression prior to the Santonian, but has subsequently been partially infilled, as the present-day canyon is much more areally restricted (Fig. 12). Such an interpretation is further supported by the fact that this area has the largest negative Bouger gravity anomaly ( $-70 \mathrm{mgal})$ in all of the Bahamas (Talwani, 1960), suggesting the presence of thick, anomalously low-density material.

As the margin north of LBB marks the present boundary between the Blake Plateau and Bahamas (Fig. 1), the slope there could not have developed until the Blake Plateau had completely drowned. The exact timing of the demise of the "shallow-water" Blake Plateau, however, is not fully known. DSDP data from the Blake Nose indicate that this portion of the Blake Plateau drowned during the Early Cretaceous (Barremian; Benson, Sheridan, et al., 1978). Yet most of the central Blake Plateau remained a shallow-water environment until near the end of the Albian (Dillon, Paull, Dahl, et al., 1979; Sheridan, et al., 1981) or the end of the Santonian (Sheridan and Enos, 1979). Furthermore, our seismic stratigraphy suggests that the southernmost Blake Plateau was not drowned until near the end of the Cretaceous (top of NLBB-3), which is supported by the recovery of Late Cretaceous shallow-water limestones as young as Campanian-Maestrichtian from the Great Ab- 


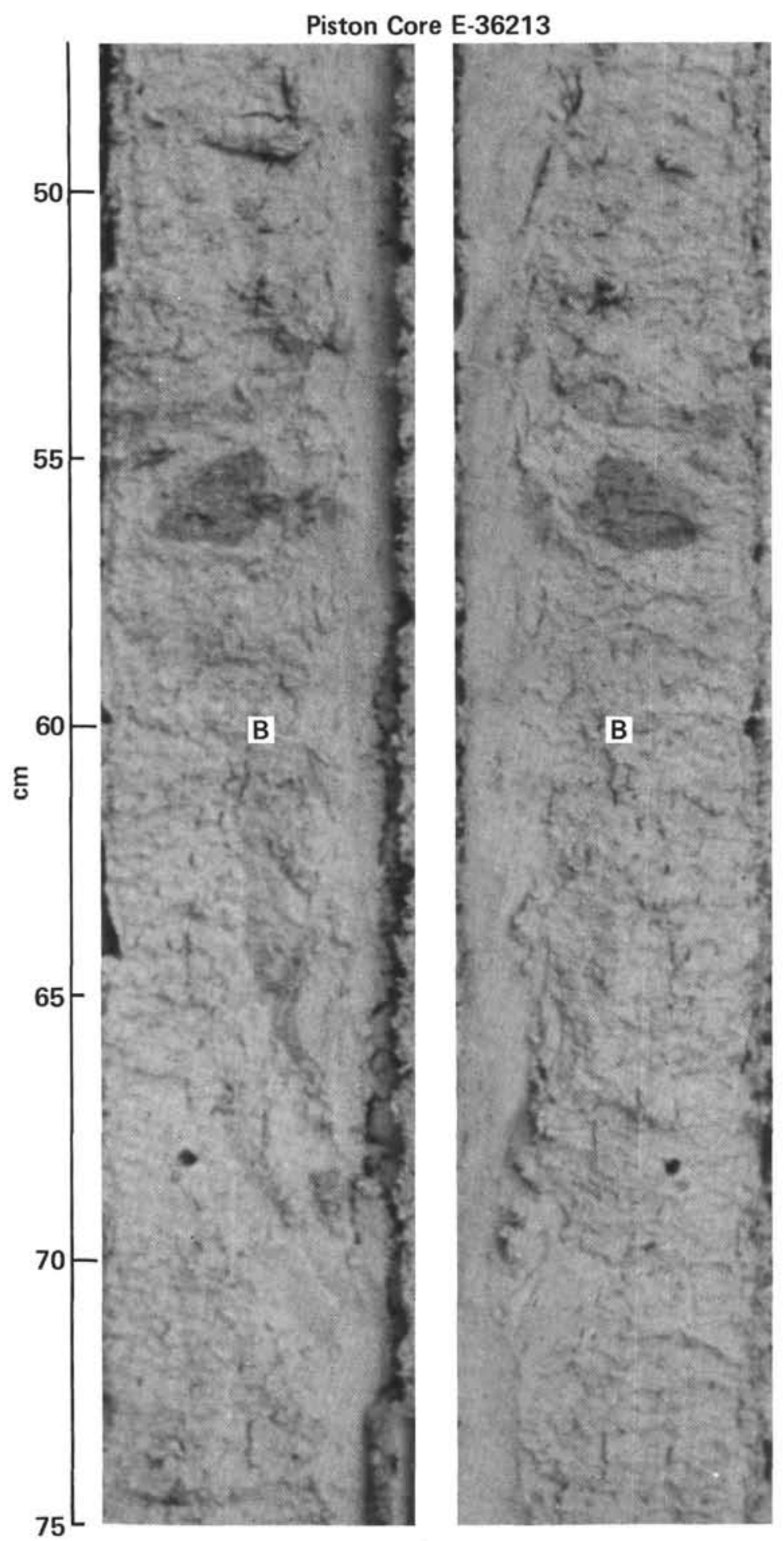

Figure 9. Photograph of split piston core \#21 (E-36213) from $850 \mathrm{~m}$ of water along the upper slope north of Little Bahama Bank. (Fine-grained sediments are heavily bioturbated. Large circular burrows up to $2 \mathrm{~cm}$ across [B] as well as numerous, thin vertical burrows [black lines] are present.)

aco Canyon (Sheridan, et al., 1971; Mullins et al., 1982). Thus it appears that drowning of the Blake Plateau was not a synchronous event, but rather time-transgressive.

The cause of this drowning is also not fully understood, although Jansa (1981) and Schlager (1981) have linked the demise of Mesozoic carbonate platforms along the eastern continental margin of North America to plate tectonic drift. Such drift, out of the zone of tropical carbonate sedimentation, coupled with sea-level fluctuations, regional passive-margin subsidence, and possibly local tectonics, may explain the time-transgressive drowning of the Blake Plateau. 


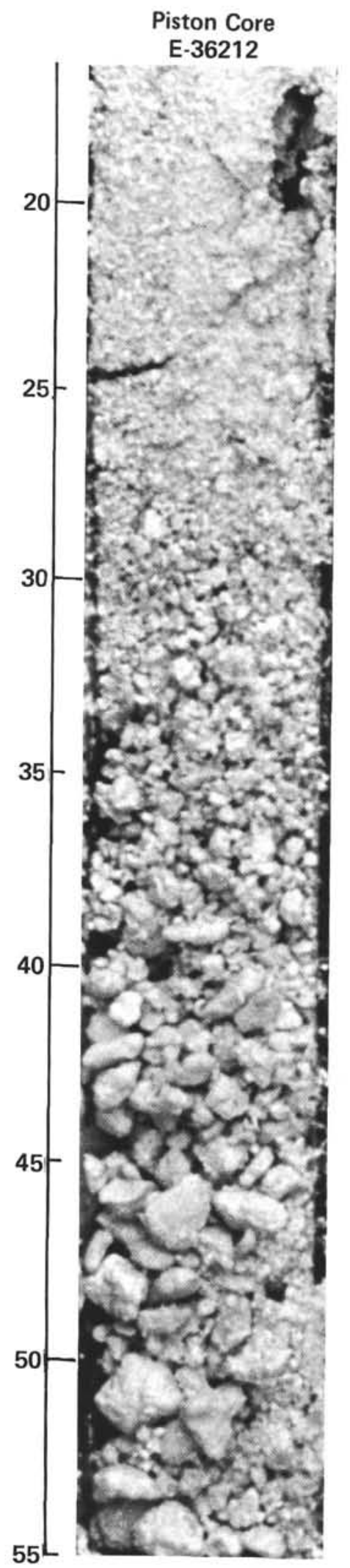

Figure 10. Photograph of one-half of split piston core \#20 (E-36212) collected from $1095 \mathrm{~m}$ of water along the lower slope north of Little Bahama Bank. (Core exhibits distinct normal grading [turbidite] from gravel to finer sands.)

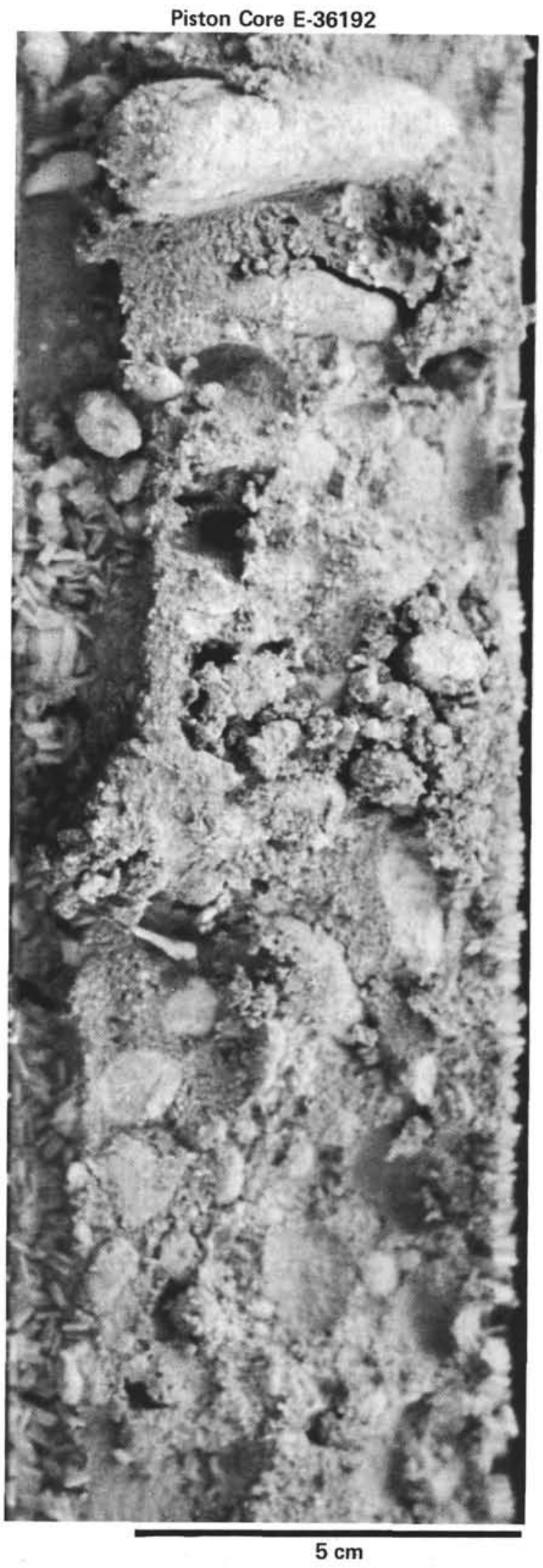

Figure 11. Photograph of one-half of split piston core \#2 (E-36192) collected at a depth of $1000 \mathrm{~m}$ from the lower slope north of Little Bahama Bank. (Note poorly sorted fabric with "floating" clasts, which we interpret as debris-flow deposit.) 
Table 1. Summary of seismic stratigraphy and geologic development of the northern margin of LBB.

\begin{tabular}{|c|c|c|c|c|c|}
\hline \multicolumn{2}{|c|}{ Seismic sequences } & \multirow[b]{2}{*}{$\begin{array}{l}\text { Assumed } \\
\text { velocity } \\
(\mathrm{km} / \mathrm{s})^{\mathrm{a}}\end{array}$} & \multirow[b]{2}{*}{ Age } & \multirow[b]{2}{*}{$\begin{array}{l}\text { Time } \\
\text { (m.y.) }\end{array}$} & \multirow[b]{2}{*}{ Major events } \\
\hline $\begin{array}{l}\text { Northern } \\
\text { LBB }\end{array}$ & $\begin{array}{l}\text { Correlative } \\
\text { sequence of } \\
\text { Shipley et } \\
\text { al. (1978) }\end{array}$ & & & & \\
\hline NLBB-4 & BP-4 & 4.56 & Pre-Campanian & $98-80$ & $\begin{array}{l}\text { LBB and Blake Plateau formed one continuous shallow-water } \\
\text { carbonate platform, with the exception of the Great } \\
\text { Abaco Canyon area, which was a topographic depression } \\
\text { prior to the Santonian }\end{array}$ \\
\hline NLBB-3 & BP-3 & 3.03 & $\begin{array}{l}\text { Campanian- } \\
\text { Maestrichtian }\end{array}$ & $80-65$ & $\begin{array}{l}\text { A shallow-water carbonate platform persisted along the } \\
\text { northwestern margin of LBB, whereas a slope environment } \\
\text { extended from northeastern LBB into headward regions } \\
\text { of the Great Abaco Canyon; drowning of carbonate plat- } \\
\text { form at end of the Cretaceous due to plate tectonic drift, } \\
\text { sea-level changes, regional subsidence, and local tectonics. }\end{array}$ \\
\hline NLBB-2 & BP-2 & 2.40 & $\begin{array}{l}\text { Paleocene- } \\
\text { late } \\
\text { Oligocene }\end{array}$ & $65-30$ & $\begin{array}{l}\text { Deep carbonate bank margin developed along northwestern } \\
\text { LBB after drowning of a shallow-water carbonate plat- } \\
\text { form; periplatform oozes accumulated along upper slope, } \\
\text { and carbonate sediment gravity flows along lower slope; } \\
\text { extensive slope instability and submarine sliding; major } \\
\text { erosional event } \sim 30 \mathrm{Ma}\end{array}$ \\
\hline NLBB-1 & BP-1 & 1.92 & $\begin{array}{l}\text { late Oligocene- } \\
\text { Recent }\end{array}$ & $30-0$ & $\begin{array}{l}\text { Entire margin built up and out after a submarine erosional } \\
\text { event caused by intensified oceanic circulation in the late } \\
\text { Oligocene; periplatform oozes accumulated on upper } \\
\text { slope, and slide blocks, turbidites and debris flow deposits } \\
\text { on lower slope; slope instability and generation of carbon- } \\
\text { ate sediment gravity flows continued; recurrent faulting } \\
\text { along Walker's Cay Fault }\end{array}$ \\
\hline
\end{tabular}

a Based on Sheridan et al. (1966).

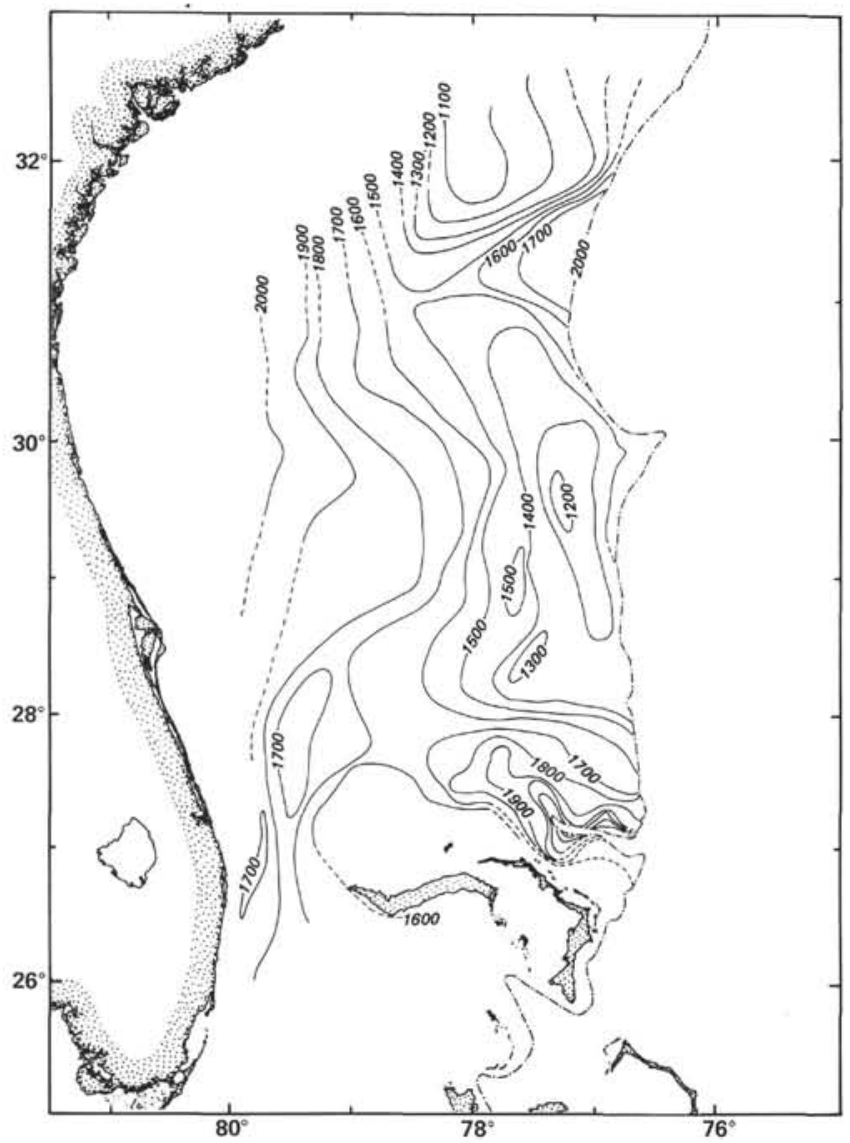

Figure 12. Structure contour map, using sea level as datum on top of reflector 4 (top NLBB-4) for Blake Plateau. (Note large embayment of contours along northeastern margin of the Little Bahama Bank in the vicinity of the Great Abaco Canyon. Contours are in meters. From Ewing et al. (1966), with permission of American Association of Petroleum Geologists Bulletin and J. Ewing.)
Once the Blake Plateau had completely drowned, a carbonate slope was able to develop along the entire northern margin of LBB. This transition from shallowwater to deeper-water carbonate sedimentation north of LBB is defined by the downlap of chaotic, discontinuous reflectors of sequence NLBB-2 onto the top of even, parallel, continuous reflectors of sequence NLBB-3 (Fig. 4). Our reflection data suggest that slope development here was more or less a continuous process, with the accumulation of periplatform oozes along the upper slope, and submarine slide as well as carbonate sediment gravity flow deposits along the lower slope. Such depositional patterns were initiated in the early Tertiary and continue through the present (Mullins, Van Buren, et al., 1981; Van Buren and Mullins, 1981), as the entire slope has built both up and out.

Slope sedimentation north of LBB was interrupted only once, during the late Oligocene, by submarine erosion. Truncated reflectors at the top of sequence NLBB2 and distinct downlap of the overlying unit (Fig. 8) define a major unconformity. Submarine erosion at this time may have been initiated by an oceanic cooling event and major sea-level fall (Fig. 6). If this erosion occurred during the late Oligocene, it may be correlative with the " $\mathrm{A}$ " " unconformity in the western North Atlantic, which is a major submarine erosional surface (Paull and Dillon, 1980; Tucholke, 1981). A block diagram summarizing our results is presented as Figure 14.

Our evidence for extensive submarine sliding and generation of carbonate sediment gravity flows north of LBB throughout the Cenozoic lends support to the suggestions of Benson, Sheridan, et al. (1978) that this slope may have been a source area for thick, Miocene gravity flow deposits drilled in the Blake-Bahama Basin (also, see Bleifnick and Roberts, this volume). Benson, Sheridan, et al. (1978) have previously proposed that 


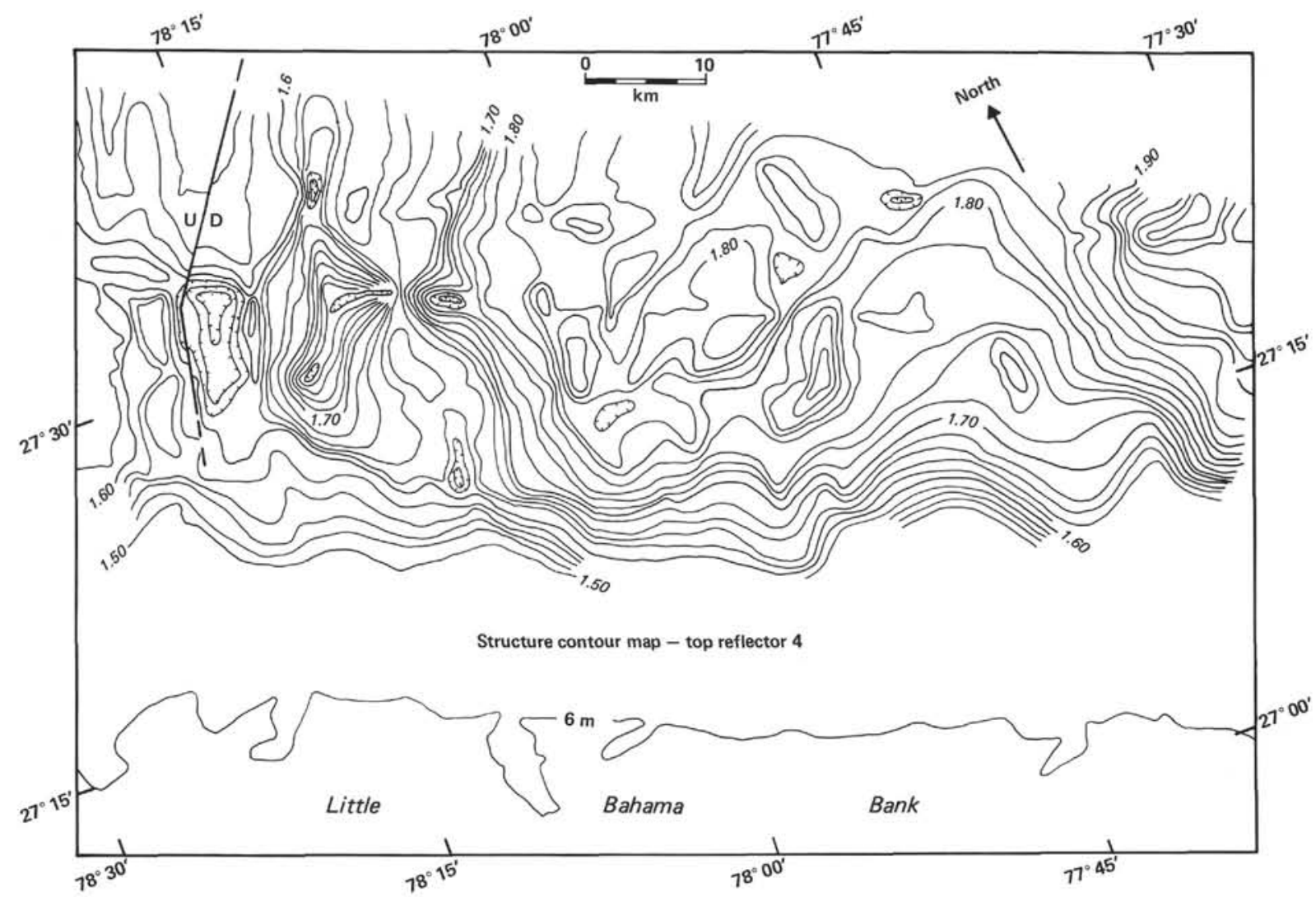

Figure 13. Structure contour map using sea level as datum on top of reflector 4 (depositional sequence NLBB-4) north of the Little Bahama Bank. (Note embayment of contours in the eastern portion of the study area as well as Walkers Cay Fault [Mullins and Van Buren, 1981] to the west. The map, based on air-gun data in Fig. 2, was corrected for velocity variations using refraction data of Sheridan et al. (1966). Contours are in kilometers. $\mathrm{D}=$ down-thrown side of fault; $\mathrm{U}=$ up-thrown side of fault.)

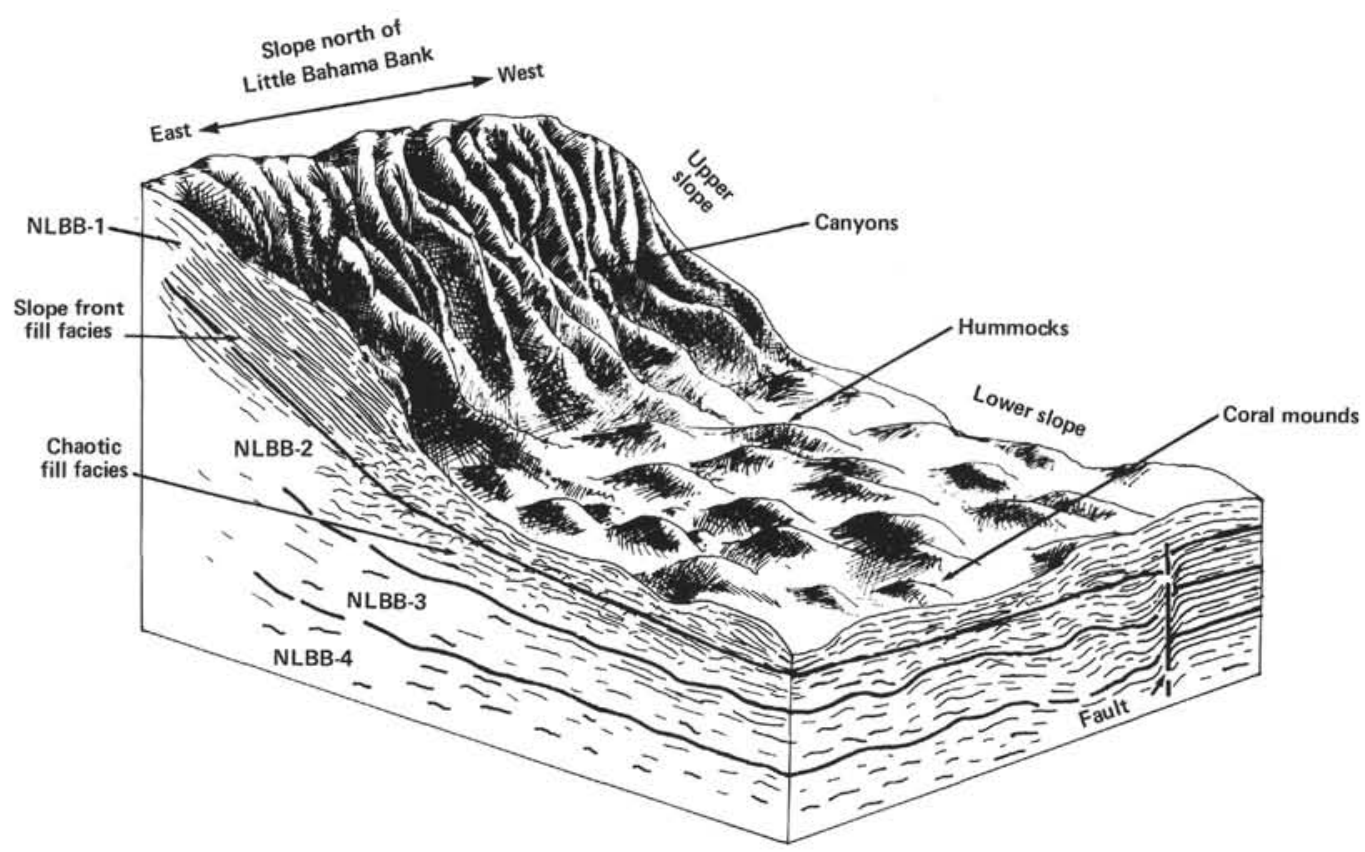

Figure 14. Schematic block diagram depicting surface morphology (exaggerated) and seismic stratigraphic units north of the Little Bahama Bank. (View is looking to the southwest from the Blake Plateau. No scale is implied. Surface morphology was drawn by Ted Jeremko.) 
submarine slides along the southern Blake Plateau/ northern Bahamas were funnelled into the Great Abaco Canyon and/or the Northeast Providence Channel and ultimately deposited in the Blake-Bahama Basin (Fig. 1). According to Benson, Sheridan, et al. (1978), sedimentation occurred during periods of high sea level, coupled with regional/local tectonic "shaking."

\section{CONCLUSIONS}

Geologic development of the carbonate slope north of LBB has been complex. A structural depression existed northeast of LBB prior to the Santonian in the present vicinity of the Great Abaco Canyon. This depression was probably lined with carbonate slopes and partially infilled by sediment shed into it. The present slope north of LBB did not develop until after the complete drowning of the southern Blake Plateau near the end of the Cretaceous. Drowning of the plateau may be related to plate tectonic drift, coupled with regional subsidence, sea-level oscillations, and local tectonics.

The slope north of LBB has accreted laterally as a bypass margin beginning in the early Tertiary and continues to do so today. Periplatform oozes accumulated along the upper slope as a slope front fill facies, whereas submarine slide and carbonate sediment gravity flow deposits accumulated along the lower slope in the form of a base-of-slope apron that strikes parallel to the adjacent shelf edge. However, during the late Oligocene, this slope became an eroded margin as a result of submarine erosion, possibly correlative with the " $A$ " " unconformity in the western North Atlantic. Overall, we conclude that lateral accretion, sediment bypassing, and submarine erosion have interacted during regional passive margin subsidence, sea-level fluctuations, and local tectonics to produce a single, open-ocean carbonate slope.

\section{ACKNOWLEDGMENTS}

Ship time aboard Duke University's Eastward was provided as part of a National Science Foundation grant to A. C. Neumann and A. C. Hine at the University of North Carolina. We thank W. P. Dillon, A. C. Hine, and S. D. Locker for their reviews of this manuscript. We also thank R. E. Sheridan and F. M. Gradstein for helpful comments and for inviting us to contribute to this volume.

\section{REFERENCES}

Benson, W. E., Sheridan, R. E., et al., 1978. Init. Repts. DSDP, 44: Washington (U.S. Govt. Printing Office).

Crevello, P. D., and Schlager, W., 1980. Carbonate debris sheets and turbidites, Exuma Sound, Bahamas. J. Sediment. Petrol., 50: 1121-1148.

Dillon, W. P., Paull, C. K., Buffler, R. T., and Fail, J. P., 1979. Structure and development of the southeast Georgia embayment and northern Blake Plateau: preliminary analysis. Am. Assoc. Pet. Geol. Mem., 29:27-41.

Dillon, W. P., Paull, C. K., Dahl, A. G., and Patterson, W. C., 1979. Structure of the continental margin near the COST No. GE-1 drill site from a CDP seismic reflection profile. U.S. Geol. Surv. Circ., 800:97-108.

Ewing, J., Ewing, M., and Leyden, R., 1966. Seismic profiler survey of Blake Plateau. Am. Assoc. Pet. Geol. Bull, 50:1948-1971.

Hine, A. C., and Neumann, A. C., 1977. Shallow carbonate bank margin growth and structure, Little Bahama Bank, Bahamas. Am. Assoc. Pet. Geol. Bull., 61(3):376-406.

Hine, A. C., Wilber, R. J., Bane, J. M., Neumann, A. C., and Lorenson, K. A., 1981. Offbank transport of carbonate sands along open, leeward bank margins, northern Bahamas. Mar. Geol., 42: 327-348.

Jansa, L. F., 1981. Mesozoic carbonate platforms and banks of the eastern North American margin. Mar. Geol., 44:97-118.

JOIDES, 1965. Ocean drilling on the continental margin. Science, 150:709-716.

King, P. B., 1969. Tectonic map of North America: Washington (U.S. Geol. Surv. G67154).

Lighty, R. G., 1981. Fleshy-algal domination of a modern Bahamian barrier reef: example of an alternate climax reef community. Fourth Int. Symp. Coral Reefs, Manila, Phillippines, p. 37.

Locker, S. D., 1980. Origin and depositional history of a semi-enclosed windward lagoon off Great Abaco Island, Bahamas [M.S. thesis]. University of North Carolina, Chapel Hill.

Lynts, G. W., Judd, J. B., and Stehman, C. F., 1973. Late Pleistocene history of Tongue of the Ocean, Bahamas. Geol. Soc. Am. Bull., 84:2665-2684.

Mitchum, R. M., Vail, P. R., and Sangree, J. B., 1977. Stratigraphic interpretation of seismic reflection patterns in depositional sequences. Am. Assoc. Pet. Geol. Mem., 26:117-134.

Mitchum, R. M., Vail, P. R. and Thompson, S., 1977. Depositional sequence as a basic unit for stratigraphic analysis. Am. Assoc. Pet. Geol. Mem., 26:53-62.

Mullins, H. T., Keller, G. H., Kofoed, J. W., Lambert, D. N., Stubblefield, W. L., and Warme, J. E., 1982. Geology of Great Abaco Submarine Canyon: observations from the research submersible Alvin. Mar. Geol., 48:239-257.

Mullins, H. T., and Neumann, A. C., 1979. Deep carbonate bank margin structure and sedimentation in the northern Bahamas. Soc. Econ. Paleontol. Mineral. Spec. Publ., 27:165-192.

Mullins, H. T., Neumann, A. C., Wilber, R. J., and Boardman, M. R., 1980a. Nodular carbonate sediment on Bahamian slopes: possible precursors to nodular limestones. J. Sediment. Petrol., 50(1): $117-131$.

Mullins, H. T., Neumann, A. C., Wilber, R. J., Hine, A. C., and Chinburg, S. J., 1980b. Carbonate sediment drifts in northern Straits of Florida. Am. Assoc. Pet. Geol. Bull., 64(10):1701-1717.

Mullins, H. T., Newton, C. R., Heath, K., and Van Buren, H. M., 1981. Modern deep-water coral mounds north of Little Bahama Bank: criteria for the recognition of deep-water coral bioherms in the rock record. J. Sediment. Petrol., 51:999-1013.

Mullins, H. T., and Van Buren, H. M., 1981. Walkers Cay Fault, Bahamas: evidence for Cenozoic faulting. Geo. Mar. Lett., 1:225-231.

Mullins, H. T., Van Buren, H. M., Davis, R. A., Heath, K., and Newton, C. R., 1981. Anatomy of a modern open-ocean windward carbonate slope: northern Little Bahama Bank. Am. Assoc. Pet. Geol. Bull., 65:962-963. (Abstract)

Paull, C. K., and Dillon, W. P., 1980. Erosional origin of the Blake Escarpment: an alternative hypothesis. Geology, 8:538-542.

Payton, C. E. (Ed.), 1977. Seismic stratigraphy-applications to hydrocarbon exploration. Am. Assoc. Pet. Geol. Mem., 26:516.

Sangree, J. B., and Widmier, J. M., 1977. Seismic interpretation of clastic depositional facies. Am. Assoc. Pet. Geol. Mem., 26: 165-184.

Schlager, W., 1981. The paradox of drowned reefs and carbonate platforms. Geol. Soc. Am. Bull., 92:197-211.

Schlager, W., and Chermak, A., 1979. Sediment facies of platformbasin transition, Tongue of the Ocean, Bahamas. Soc. Econ. Paleontol. Mineral. Spec. Publ., 27:193-208.

Schlager, W., and Ginsburg, R. N., 1981. Bahama carbonate platforms-the deep and the past. Mar. Geol., 44:1-24.

Sheridan, R. E., 1981. Geophysical recognition and structure of carbonate platforms and platform edges on passive continental margins. Mar. Geol., 44:171-180.

Sheridan, R. E., Berman, R. M., and Corman, D. B., 1971. Faulted limestone block dredged from Blake Escarpment. Geol. Soc. Am. Bull., 82:199-206.

Sheridan, R. E., Crosby, J. T., Bryan, G. M., and Stoffa, P. L., 1981. Stratigraphy and structure of southern Blake Plateau, northern Florida Straits and northern Bahama Platform from multichannel seismic reflection data. Am. Assoc. Pet. Geol. Bull., 65(12): 2571-2593.

Sheridan, R. E., Drake, C. L., Nafe, J. E., and Hennion, J., 1966. Seismic refraction study of continental margin east of Florida. Am. Assoc. Pet. Geol. Bull., 50:1972-1990. 
Sheridan, R. E., and Enos, P., 1979. Stratigraphic evolution of the Blake Plateau after a decade of scientific drilling. Am. Geophys. Union, Maurice Ewing Series, 3:109-122.

Sheridan, R. E., and Osburn, W. L., 1975. Marine geologic and geophysical studies of the Florida-Blake Plateau-Bahamas area. Can. Soc. Pet. Geol. Mem., 9:9-32.

Shipley, T. H., Buffler, R. T., and Watkins, J. S., 1978. Seismic stratigraphy and geologic history of Blake Plateau and adjacent western Atlantic continental margin. Am. Assoc. Pet. Geol. Bull, 62: 792-812.

Talwani, M., 1960. Gravity anomalies in the Bahamas and their interpretation [Ph.D. dissert.]. Columbia University, New York.
Tucholke, B. E., 1981. Geologic significance of seismic reflectors in the deep western North Atlantic basin. Soc. Econ. Paleontol. Mineral. Spec. Publ., 32:23-37.

Vail, P. R., Mitchum, R. M., and Thompson, S., 1977. Global cycles of relative changes of sea level. Am. Assoc. Pet. Geol. Mem., 26:83-98.

Van Buren, H. M., and Mullins, H. T., 1981. Seismic stratigraphy of a modern carbonate slope. Am. Assoc. Pet. Geol. Bull., 65:1004.

Date of Initial Receipt: March 29, 1982 